\title{
Heavy metal tolerance in association with plasmid mediated multiple antibiotic resistances among clinical bacterial isolates
}

\author{
Saumendra Nath Das ${ }^{1}$, Manisha Mandal ${ }^{2}$ and Shyamapada Mandal ${ }^{1 *}$ \\ ${ }^{1}$ Department of Zoology, University of Gour Banga, Malda, India \\ ${ }^{2}$ Department of Physiology, MGM Medical College and LSK Hospital, Bihar, India
}

\begin{abstract}
The heavy metal tolerance in association with plasmid mediated antibiotic resistance among bacteria has been reported around the globe. This communication conducted an experiment to explore the co-existence of antibiotic resistance and heavy metal tolerance in clinical bacteria and the involvement of R-plasmid in such phenomenon. By disc diffusion method, 6 clinical bacteria: Escherichia coli $(\mathrm{n}=3)$, Pseudomonas aeruginosa $(\mathrm{n}=2)$ and Proteus mirabilis $(\mathrm{n}=1)$, utilized in the study, displayed resistance to multiple antibiotics with MAR (multiple antibiotic resistance) indices 0.15 - 0.77 ; such bacterial isolates showed tolerance to $\mathrm{Hg}^{2+}, \mathrm{Cd}^{2+}, \mathrm{Cr}^{6+}$ and $\mathrm{Cu}^{2+}$ at $3-37.5 \mu \mathrm{g} / \mathrm{ml}, 75-800 \mu \mathrm{g} / \mathrm{ml}, 100-400 \mu \mathrm{g} /$ $\mathrm{ml}$ and $600-900 \mu \mathrm{g} / \mathrm{ml}$, respectively. The SDS treatment induced the test bacteria to mislay their resistance property (following susceptibility test) with a parallel loss of single plasmid (following agarose gel electrophoretic analysis) contained in them. This study confirms the antibiotic co-resistance with heavy metal tolerance among human pathogenic bacteria, and underlines the regular vigilance of bacterial R-plasmid in order to combat the multiple antibiotic resistances of such bacteria as well as the infection caused by them.
\end{abstract}

KEY WORDS: HUMAN PATHOGENIC BACTERIA, R-PLASMID, HEAVY METAL TOLERANCE, ANTIBIOTIC RESISTANCE, MAR INDEX

\section{INTRODUCTION}

The antibiotics, which are still the gold standard therapeutics against a large number of bacterial infections, and the heavy metals, which are in use in various anthro-

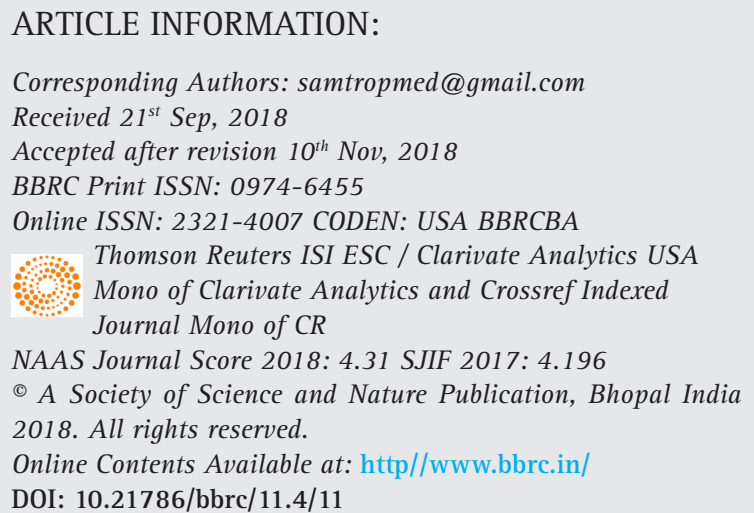

pogenic activities, remain the two universal categories of environmental pollutants, and are unsafe to public health and biological safety (Zhu et al., 2013). Several anthropogenic processes cause contamination of environment with heavy metals leading to the selection and 
emergence of bacteria possessing the tolerance capacity to heavy metals in the niches (Nakahara et al., 1977), and, as such, the heavy metal accumulation in the environment accounts for the bacterial antibiotic co-resistance (Baker-Austin et al., 2006; Berg et al., 2010; Das et al., 2016). The imprudent use of antibiotics, on the other hand, results emergence of antibiotic resistant bacteria having the capacity to cause life-threatening infection to humans, around the world (Tenover, 2006; Mandal 2015). It has been reported that the exposure of heavy metals causes an effect in the co-selection of metal tolerant and antibiotic resistant bacteria (Filali et al., 2000), and such co-resistances are plasmid mediated (Smith, 1967; Das et al., 2018). Garhwal et al. (2014) observed a significant change in MAR (multiple antibiotic resistance) index in clinical bacterial isolates before and after lead $\left(\mathrm{Pb}^{2+}\right)$ exposure. Nakahara et al. (1977) studied the frequency of antibiotic and heavy metal resistance in clinical isolates of Escherichia coli, Klebsiella pneumoniae, Pseudomonas aeruginosa, and reported a similar as well as different heavy-metal resistance frequency, when compared to the antibiotic resistance frequency, among the isolates, and such resistances were proved to be plasmid mediated. The occurrence of R-plasmid (antibiotic resistance plasmid) conferring heavy metal tolerance in river water isolates of $E$. coli and Ps. aeruginosa has been documented earlier (Das et al., 2016). The heavy metal induced antibiotic resistance in bacteria has also been reported (Chen et al., 2015). A conjugative plasmid, approximately of $56.4 \mathrm{~kb}$, encoding resistance to heavy metals $\left(\mathrm{Hg}^{2+}, \mathrm{Cu}^{2+}, \mathrm{Pb}^{2+}, \mathrm{Cd}^{2+}\right)$ as well as antibiotics was detected among nosocomial isolates of $E$. coli and $K$. pneumoniae (Karbasizaed et al., 2003). Thus, an emerging concern, predominantly in the developing countries, for the treatment of infectious disease is the acquisition and dissemination of bacterial plasmid mediated resistance to multiple antibiotics. Hence, in order to evade the bacterial antibiotic resistance, by fixing an appropriate treatment 'to-do-list', precise and prompt detection of resistance phenotype is an emergent and imperative issue (Doddaiah and Anjaneya, 2014), since bacterial antibiotic resistance has been marked as the global public health crisis (Martinez, 2008). Therefore, the current study has been undertaken to determine the association between antibiotic resistance and heavy metal tolerance among clinical bacterial isolates: E. coli, Ps. aeruginosa and Pr. mirabilis, West Bengal state, India.

\section{MATERIAL AND METHODS}

\section{BACTERIAL STRAIN AND MEDIA}

A total of 6 randomly selected clinical bacterial isolates: Escherichia coli $(\mathrm{n}=3)$, Pseudomonas aeruginosa $(\mathrm{n}=2)$ and Proteus mirabilis $(\mathrm{n}=1)$, were considered for the current study. The tests, in the current study, were carried out by the utilization of nutrient broth (for subculturing, bacterial inocula preparation and plasmid DNA isolation) and nutrient agar (for performing antibiotic susceptibility and heavy metal tolerance test) media (Hi-Media, India).

\section{ANTIBIOTIC SUSCEPTIBILITY TEST}

The antibiotic susceptibility test for the bacterial isolates were determined following Kirby-Bauer disc diffusion

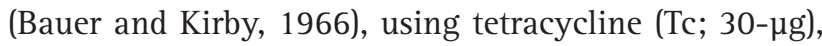
gentamicin (Gm; 10- $\mu \mathrm{g})$, cefotaxime (Ct; 30- $\mu \mathrm{g})$, cefpodoxime (Ce; 10- $\mu \mathrm{g})$, ampicillin (Am; 10- $\mu \mathrm{g})$, meropenem

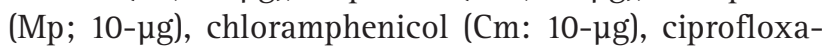
cin $(\mathrm{Cp} ; 10-\mu \mathrm{g})$, cefoxitin $(\mathrm{Cx} ; 30-\mu \mathrm{g})$, piperacillin (Pc; $100-\mu \mathrm{g})$, piperacillin/tazobactam (PT; 100/10- $\mu \mathrm{g}$ ), amikacin $(\mathrm{Ak} ; 30-\mu \mathrm{g})$ and nalidixic acid $(\mathrm{Nx} ; 30-\mu \mathrm{g})$. The results, in terms of ZDI (zone diameter of inhibition) obtained around each of the antibiotic discs, for the test isolates were interpreted according to the CLSI criteria (CLSI, 2011).

\section{MAXIMUM TOLERANCE CONCENTRATION OF HEAVY METAL}

The MTC (maximum tolerance concentration) values, for the bacterial isolates, of heavy metals: using 4 salts, such as $\mathrm{HgCl}_{2}\left(\mathrm{Hg}^{2+}\right), \mathrm{CdCl}_{2}\left(\mathrm{Cd}^{2+}\right), \mathrm{K}_{2} \mathrm{Cr}_{2} \mathrm{O}_{7}\left(\mathrm{Cr}^{6+}\right)$, and $\mathrm{CuSo}_{4}\left(\mathrm{Cu}^{2+}\right)$ were determined by agar dilution method, using $\approx 10^{4} \mathrm{CFU} /$ spot inocula, as described earlier (Das et al., 2016). The concentrations of heavy metals utilized included: $\mathrm{Hg}^{2+}(3-50 \mu \mathrm{g} / \mathrm{ml}), \mathrm{Cd}^{2+}(25-1000 \mu \mathrm{g} /$ $\mathrm{ml}), \mathrm{Cr}^{2+}(25-500 \mu \mathrm{g} / \mathrm{ml}), \mathrm{Cu}^{2+}(200-1000 \mu \mathrm{g} / \mathrm{ml})$. The obtained results were interpreted as described earlier (Das et al., 2016). The bacterial isolates grown in presence of each of the heavy metals, at concentrations $\geq 3$ $\mu \mathrm{g} / \mathrm{ml}$, were considered as heavy metal tolerant.

\section{PLASMID ANALYSIS}

As mentioned earlier (Das et al., 2016), the plasmid DNA from the test bacteria were isolated following the protocol of Kado and Liu (1981), and the agarose gel electrophoresis of the isolated plasmids were done following Maniatis et al. (1982). The plasmid DNA bands, in the gel after ethidium bromide staining, were visualized and documented using gel-doc system.

In order to investigate the loss of plasmid, the randomly selected bacterial isolates (Pr. mirabilis CSD1, Ps. aeruginosa CSD3, and E. coli CSD5) were subjected to plasmid curing with SDS, following the protocol of Anjanappa et al. (1993), as described elsewhere (Mandal et al., 2008; Das et al., 2016). The loss of antibiotic 
resistance and heavy metal tolerance, along with the loss of plasmid, was determined based on the resistance patterns of the cured bacterial strains, and absence of plasmid in the gel following agarose gel electrophoresis for the cured bacterial strains.

\section{RESULTS AND DISCUSSION}

The antibiotic susceptibility test results, in terms of ZDI, are depicted in Table 1. The mounting use of antibiotics, not only in health care but also in agriculture and animal husbandry contribute to an emergent problem of antibiotic resistant bacteria (Dhanorkar and Tambekar, 2004). Pokhrel et al. (2018) reported, among the isolated environmental bacteria, 3-antibiotic resistance, 4 to 10 -antibiotic resistances and more than 10-antibiotic resistance in $6.1 \%, 44.89 \%$ and $48.97 \%$ isolates, respectively. The fecal as well as soil isolates of Klebsiella, Citrobacter, Shigella and Staphylococcus, showed resistance to $6-10$ antibiotics tested, and the MAR indices for the isolates ranged 6 - 10 (Ayandele et al., 2018). The Mahananda river water bacterial isolates had resistance to multiple antibiotics, among $\mathrm{Am}, \mathrm{Cm}, \mathrm{Ce}, \mathrm{Cx}$ and $\mathrm{Tm}$, as per the report of the earlier study (Das et al., 2016). In the current study, Pr. mirabilis ( $\mathrm{n}=1$ ) had 2-drug resistance "Cx-Pc", Ps. aeruginosa isolates $(\mathrm{n}=2)$ had 8-drug resistance of two different patterns "Am-Ce-Cm-Ct-CxNx-Pc-PT" and "Am-Ce-Cp-Ct-Cx-Nx-Pc-PT", and the
E. coli isolates $(\mathrm{n}=3)$ showed 3 different patterns of resistance to antibiotics: 8-drug resistance "Am-Ce-Cm$\mathrm{Cp}-\mathrm{Cx}-\mathrm{Mp}-\mathrm{Nx}-\mathrm{Pc}$ ", 9-drug resistance "Am-Ce-Cp-CtCx-Mp-Nx-Pc-PT" and 10-drug resistance "Am-Ce-CpCt-Cx-Mp- Nx-Pc-PT-Tc" (Table 2). As per the report of Malema et al. (2018), among the 100 pathogenic E. coli test isolates, $52 \%$ had multiple antibiotic resistance, of which 10 showed to 9 antibiotics, and 24 different MAR phenotypes have been identified.

The MAR indices for the human pathogenic bacteria are depicted in Figure 1. As has been reported by Sandhu et al. (2016), the majority of the clinical isolates of Acinetobacter had resistance to cotrimoxazole, $\mathrm{Cp}, \mathrm{Gm}, \mathrm{Ak}$, A/S, cefepime, Im, Mp, with overall MAR indices of 0.3 - 1.0 for the isolates. Subramani et al. (2012) reported high MAR indices (0.64 - 0.74) among Staphylococcus aureus isolates from clinical settings demonstrating the origin of the bacteria from niches with high antibiotic exposure/contamination. The MAR indices of potential pathogenic bacteria, E. coli (MAR index: 0.44) and Ps. aeruginosa (MAR index: 0.43-0.57), were all >0.2, indicating their origin from high risk source of antibiotic contaminated region (Oko et al., 2016). In the previous communication, the MAR indices have been reported to be 0.47 in Ps. aeruginosa and zero to 0.2 in E. coli isolates from Mahananda river water, Malda (India) (Das et al., 2016). In the current study, the MAR indices for the clinical bacteria were: 0.15 for Pr. mirabilis and 0.62 for Ps. aeruginosa, while the values ranged $0.62-0.77$

\begin{tabular}{|c|c|c|c|c|c|c|}
\hline \multirow[t]{2}{*}{ Antibiotic } & \multicolumn{6}{|c|}{ ZDI (mm) } \\
\hline & CSD1 & CSD2 & CSD3 & CSD4 & CSD5 & CSD6 \\
\hline Tc & 40 & 10 & 18 & 17 & 12 & 13 \\
\hline $\mathrm{Gm}$ & 27 & 15 & 30 & 26 & 20 & 20 \\
\hline $\mathrm{Ct}$ & 30 & 6 & 12 & 6 & 6 & 25 \\
\hline $\mathrm{Ce}$ & 20 & 10 & 6 & 6 & 6 & 13 \\
\hline $\mathrm{Am}$ & 20 & 6 & 6 & 6 & 6 & 6 \\
\hline $\mathrm{Mp}$ & 30 & 12 & 33 & 34 & 14 & 18 \\
\hline $\mathrm{Cm}$ & 18 & 22 & 8 & 22 & 25 & 8 \\
\hline $\mathrm{Cp}$ & 40 & 8 & 46 & 15 & 10 & 6 \\
\hline $\mathrm{Cx}$ & 14 & 6 & 6 & 6 & 6 & 11 \\
\hline Pc & 6 & 6 & 6 & 6 & 6 & 6 \\
\hline PT & 30 & 15 & 17 & 6 & 6 & 20 \\
\hline $\mathrm{Ak}$ & 30 & 20 & 18 & 30 & 26 & 15 \\
\hline $\mathrm{Nx}$ & 25 & 6 & 12 & 10 & 6 & 6 \\
\hline
\end{tabular}




\begin{tabular}{|c|c|c|c|}
\hline \multirow[t]{2}{*}{ Bacterial isolates* } & \multicolumn{2}{|c|}{ Resistance/tolerance patterns } & \multirow{2}{*}{$\begin{array}{l}\text { Resistance patterns } \\
\text { of cured bacteria }\end{array}$} \\
\hline & Antibiotic resistance & Heavy metal tolerance & \\
\hline Pr. mirabilis CSD1 & $\mathrm{Cx}-\mathrm{Pc}$ & $\mathrm{Hg}^{2+}-\mathrm{Cd}^{2+}-\mathrm{Cr}^{6+}-\mathrm{Cu}^{2+}$ & Pc \\
\hline E. coli CSD2 & $\begin{array}{l}\text { Am-Ce-Cp-Ct-Cx-Mp-Nx-Pc- } \\
\text { PT-Tc }\end{array}$ & $\mathrm{Hg}^{2+}-\mathrm{Cd}^{2+-}-\mathrm{Cr}^{6+}-\mathrm{Cu}^{2+}$ & ND \\
\hline Ps. aeruginosa CSD3 & Am-Ce-Cm-Ct-Cx-Nx-Pc-PT & $\mathrm{Hg}^{2+}-\mathrm{Cd}^{2+}-\mathrm{Cr}^{6+}-\mathrm{Cu}^{2+}$ & Nx-Pc-PT \\
\hline Ps. aeruginosa CSD4 & Am-Ce-Cp-Ct-Cx-Nx-Pc-PT & $\mathrm{Hg}^{2+}-\mathrm{Cd}^{2+}-\mathrm{Cr}^{6+}-\mathrm{Cu}^{2+}$ & ND \\
\hline E. coli CSD5 & Am-Ce-Cp-Ct- Cx-Mp-Nx-Pc-PT & $\mathrm{Hg}^{2+}-\mathrm{Cd}^{2+}-\mathrm{Cr}^{6+}-\mathrm{Cu}^{2+}$ & Cp-Mp-Nx-Pc-PT \\
\hline E. coli CSD6 & Am-Ce-Cm- Cp-Cx- Mp-Nx-Pc & $\mathrm{Hg}^{2+}-\mathrm{Cd}^{2+}-\mathrm{Cr}^{6+}-\mathrm{Cu}^{2+}$ & ND \\
\hline \multicolumn{4}{|c|}{$\begin{array}{l}\text { *The clinical bacterial isolates possessed a single plasmid of } \approx 54 \mathrm{~kb} \text {, and the cured bacterial strains were plasmid-less. ND: } \\
\text { curing not done. } \\
\text { Am: ampicillin, Ce: cefpodoxime, Cm: chloramphenicol, Cp: ciprofloxacin, Ct: cefotaxime, Cx: cefoxitin, Gm: gentamycin, Mp: } \\
\text { meropenem, Nx: nalidixic acid, Pc: piperacillin, PT: piperacillin/tazobactam, Tc: tetracycline. }\end{array}$} \\
\hline
\end{tabular}

for $E$. coli isolates. Thus, considering the fact of origin of bacterial contamination from human-fecal sources, based on the MAR indices of $>0.4$ (Tambekar et al., 2005; Kaneene et al., 2007), and from high risk zone of contamination with antibiotics, based on the MAR indices of $>0.2$ (Krumperman, 1983), the currently studied clinical bacteria (Ps. aeruginosa and E. coli) might have been originated from niches with human-fecal contamination, due to antibiotic selection pressure.

The bacterial heavy metal tolerance has been depicted in Table 2. As has been reported by Mustapha and Halimoon (2015), the bacterial isolates from industrial effluents had tolerance to $\mathrm{Cd}^{2+}, \mathrm{Cr}^{6+}, \mathrm{Pb}^{2+}$ and $\mathrm{Cu}^{2+}$, at the concentration of $50 \mathrm{\mu g} / \mathrm{ml}$, while one of the isolate showed resistance to high level of $\mathrm{Cu}^{2+}(200 \mu \mathrm{g} / \mathrm{ml})$, and for one isolate the $\mathrm{Cd}^{2+}$ MIC (minimum inhibitory concentration) was recorded as high as $200 \mu \mathrm{g} / \mathrm{ml}$. Zhu et al. (2013) determined the MICs of $\mathrm{Pb}^{2+}, \mathrm{Cu}^{2+}, \mathrm{Zn}^{2+}, \mathrm{Cr}^{6+}$ and $\mathrm{Hg}^{2+}$ as 125, 100, 100, 100 and $25 \mu \mathrm{g} / \mathrm{ml}$, respectively, for the livestock isolate of Ps. fluorescens, and recorded the occurrence of enhancement of bacterial resistance to antibiotics due to the presence of some heavy metals at certain concentrations. Ps. aeruginosa, Ps. putida and Klebsiella pneumoniae had $\mathrm{Cd}^{2+}$ MICs 300 - 950 $\mu \mathrm{g} / \mathrm{ml}$; such isolates had $\mathrm{Zn}^{2+}$ MICs of 1150,1100 and $2000 \mu \mathrm{g} / \mathrm{ml}$, respectively, and $\mathrm{Hg}^{2+}$ MICs of 20, 80 and $90 \mu \mathrm{g} / \mathrm{ml}$, respectively (Yamina et al., 2014). Ps. aeruginosa and E. coli, isolated from Mahananda river water,

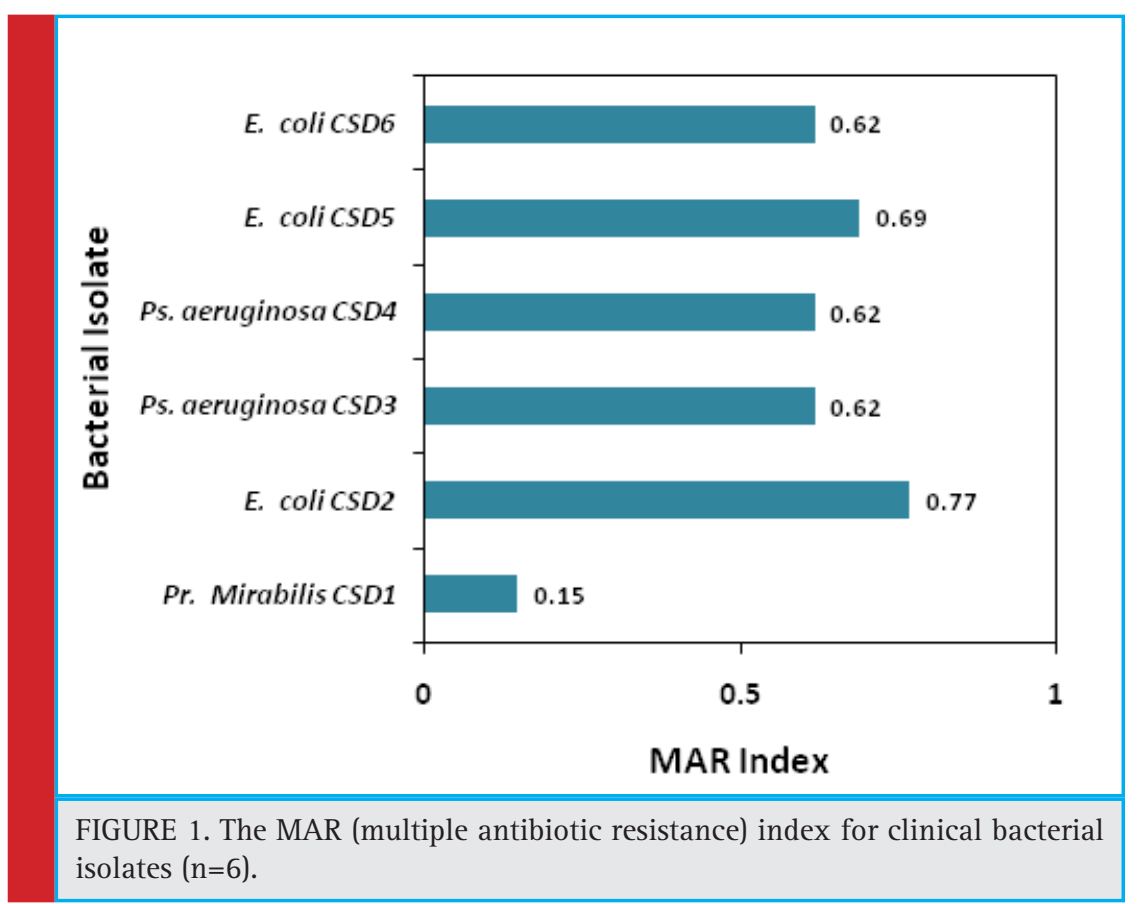




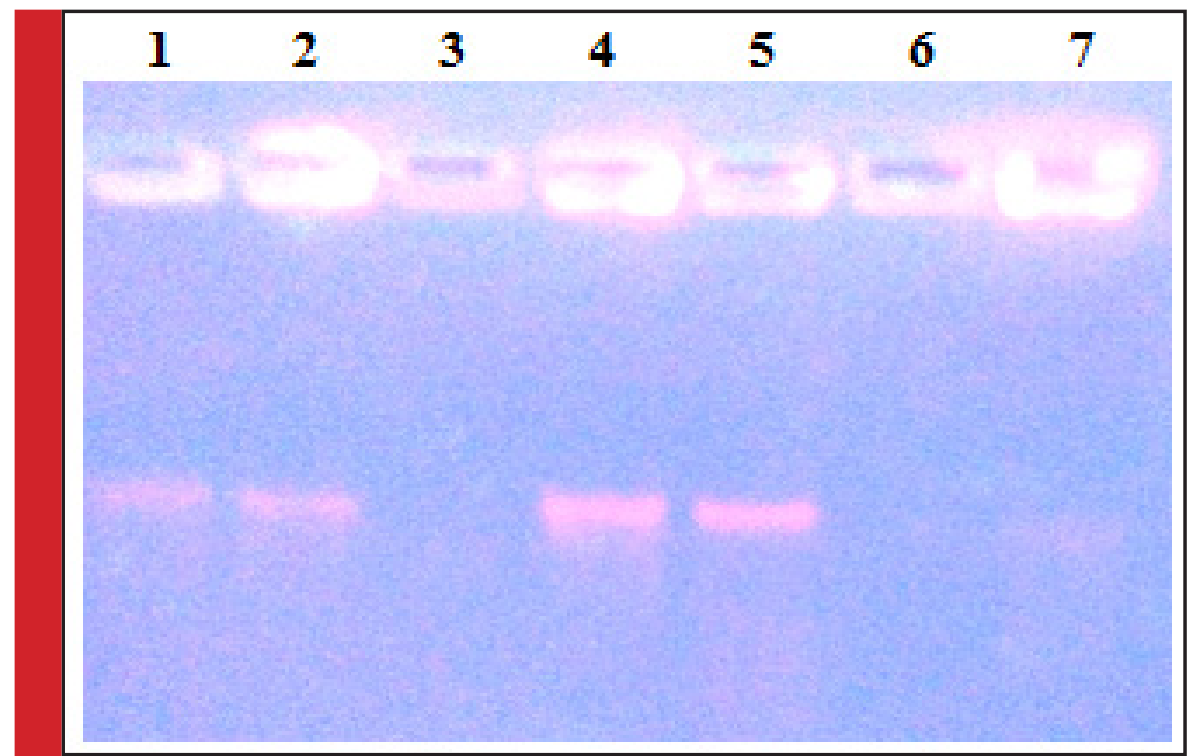

FIGURE 2. Plasmid profile of clinical bacterial isolates; lane 1: E. coli V517 (54 kb), lane 2: Pr. mirabilis CSD1, lane 3: Pr. mirabilis CSD1 (cured strain), lane 4: Ps. aeruginosa CSD3, lane 5: E. coli CSD5, lane 6: Ps. aeruginosa CSD3 (cured strain), lane 7: E. coli CSD5 (cured strain). Note the absence of plasmid in cured bacterial strains (lane 3, 6 and 7).

Malda (India) had resistance to $\mathrm{Cd}^{2+}$ and $\mathrm{Hg}^{2+}$ (Das et al., 2016). The continued usage of heavy metals since the ancient, in medicine and other anthropogenic purposes, select heavy metal resistant bacteria in polluted niches. For the bacteria utilized in the current study, the level of tolerance to $\mathrm{Hg}^{2+}, \mathrm{Cd}^{2+}, \mathrm{Cr}^{6+}$ and $\mathrm{Cu}^{2+}$ ranged $3-37.5$ $\mu \mathrm{g} / \mathrm{ml}, 75-800 \mu \mathrm{g} / \mathrm{ml}, 100-400 \mu \mathrm{g} / \mathrm{ml}$ and $600-900$ $\mu \mathrm{g} / \mathrm{ml}$, respectively (Table 3 ). This communication is, for the first as we believe, to demonstrate the heavy metal tolerance among clinical bacterial isolates of $E$. coli, Pr. mirabilis and Ps. aeruginosa from our part of the globe (West Bengal state, India).

The plasmid profile of clinical bacterial isolates and the cured derivatives are represented in Figure 2. Apprehension grows in recent times in connection with the co-selection for antibiotic resistance among bacteria on exposure to heavy metals, in several ecological niches (Wales and Davies, 2015). Because the heavy metal (pollution) acts discriminatorily as a selective agent in the emergence and propagation of antibiotic resistance among bacteria, wherein, along with the genes conferring antibiotic resistance, metal tolerance genes are also encoded in the same plasmids (Foster, 1983; Fang et al., 2016). The clinical isolates of Pseudomonas spp., as reported by Rajasekar and Mohankumar (2016), had resistance to multiple antibiotics and heavy metals, and the resistance properties were shown to be plasmid (10 $\mathrm{kb})$ mediated. A conjugative plasmid ( $\approx 56.4 \mathrm{~kb})$, carrying resistance to multiple heavy metals, such as, $\mathrm{Hg}^{2+}$, $\mathrm{Cu}^{2+}, \mathrm{Pb}^{2+}, \mathrm{Cd}^{2+}$, and also antibiotics was detected among the isolates of E. coli and K. pneumoniae causing nosocomial infections (Karbasizaed et al., 2003). Das et al.

Table 3. Heavy metal tolerance level for clinical bacterial
isolates $(\mathrm{n}=6)$


(2016) reported the occurrence of R-plasmid (antibiotic resistance plasmid) encoding heavy metal tolerance among E. coli and Ps. aeruginosa, isolated from river water. Herein, we demonstrated the involvement of $\approx 54$ $\mathrm{kb}$ plasmid (Figure 2) conferring heavy metal tolerance to $\mathrm{Hg}^{2+}, \mathrm{Cd}^{2+}, \mathrm{Cr}^{6+}$ and $\mathrm{Cu}^{2+}$, with associated multiple antibiotic resistances among the clinical bacterial isolates (Table 2).

The co-resistance to antibiotics and heavy metals has been reported among bacterial food pathogens (Wales and Davies, 2015). Wright et al. (2006) reported highest occurrence of heavy metal tolerance and antibiotic resistance among bacteria isolated from the contaminated most location, indicating the direct selection of heavy metal tolerant bacteria due to the exposure of heavy metals, thereby co-selecting bacterial antibiotic resistances. The E. coli isolates from urinary tract infection cases harbored copper/silver resistance genes, ' $p c o /$ sil' with MIC of $500-\mu \mathrm{g} / \mathrm{ml}$, presenting resistance to extended spectrum $\beta$-lactam antibiotics, too (Sutterlin et al., 2018). Co-spread of antibiotic resistance ( $\beta$-lactams: blaCTX-M; quinolones: oqxAB; aminoglycosides: aacIb-cr; amphenicols: floR; fosfomycin: fosA3) as well as the heavy metal resistance ( $\mathrm{Cu}: p c o ; \mathrm{Ag}:$ sil) genes, have been shown to be plasmid mediated (Zhu et al., 2013). The $\mathrm{Cd}^{2+}$ resistant isolates of Ps. aeruginosa and Ps. putida showed multidrug resistance to kanamycin $(\mathrm{Km})$, oxacillin $(\mathrm{Oc}), \mathrm{Nx}$ and sulfonamids, while $K$. pneumoniae had resistance to $\mathrm{Ct}$ in addition to $\mathrm{Km}, \mathrm{Oc}, \mathrm{Nx}$ and sulfonamids resistances (Yamina et al., 2014). In the earlier study, antibiotics (Am-Cm-Ce- $\mathrm{Cx}-\mathrm{Tm}$ ) and heavy metals $\left(\mathrm{Cd}^{2+}-\mathrm{Hg}^{2+}\right)$ co-resistances have been reported among the river water bacteria (Das et al., 2016). The co-resistance to heavy metals and antibiotics is, thus, a global concern, and the phenomenon among clinical bacteria, in our part of the globe, is not uncommon. The plasmid mediated resistance to the test heavy metals and to a number of antibiotics, as has been supported by SDS curing, approved the fact of heavy metal-antibiotic co-resistance in Ps. aeruginosa, E. coli, and Pr. mirabilis clinical isolates. The bacterial isolates displaying MAR indices of $>0.4$ have been regarded to be derived from human-fecal contaminated niches (Tambekar et al., 2005; Kaneene et al., 2007) and the bacterial isolates, with MAR indices of $>0.2$, deemed to be originated from highly antibiotic polluted regions (Krumperman, 1983). Still, the heavy metal inducing phenomenon of bacterial antibiotic resistances suggests that the emergence of multiple antibiotic resistant bacteria might be due to either the heavy metal or the antibiotic selection pressure, or both, and hence the bacterial high MAR index does also mean their (bacteria) origin from a region with high metal pollution, too.

\section{CONCLUSION}

The human pathogenic bacteria (Ps. aeruginosa, E. coli, and Pr. mirabilis) had resistance to two or more antibiotics, which in association with heavy metal resistance were found to be plasmid linked. This study endorses the dissemination of bacterial antibiotic resistance under the heavy metal as well as antibiotic selective pressure. Therefore, regular inspection of antibiotic resistance plasmid among human pathogenic bacteria, from our part of the globe, is urgently needed, in order to combat the bacterial multiple antibiotic resistance as well as the bacterial infection to humans.

\section{REFERENCES}

Anjanappa, M., Horbola, P.C., Verma, J.C. (1993). Elimination (curing) of R-plasmids in Salmonella gallinarum and their transconjugants. Indian Veterinary Journal, 70, 10-13.

Ayandele, A.A., Owolabi1, L. O., Oladeinde1, A. A., Aseweje, I. B., Oshodi, E. A. (2018). Prevalence of multi-antibiotic resistant bacteria in birds faecal and soil samples from Poultry farms in Ogbomoso, Oyo State, Nigeria. Journal of Advances in Medicine and Medical Research 26(1): 1-10; Article no.JAMMR.39868.

Baker-Austin, C., Wright, M.S., Stepanauskas R., McArthur J.V. (2006). Coselection of antibiotic and metal resistance. Trends Microbiol, 14, 176-182.

Bauer, A.W., Kirby, W.M.M., Skerris, J.C., Turuck, M. (1966). Antibiotic susceptibility testing by a standard single diffusion method. American Journal Clin Pathol, 45, 494-496.

Berg, J., Thorsen, M.K., Holm, P.E., Jensen. J., Nybroe, 0., Brandt, K.K. (2010). Cu exposure under field conditions coselects for antibiotic resistance as determined by a novel cultivation-independent bacterial community tolerance assay. Environmental Science Technology, 44, 8724-8728.

Chen, S., Xiaomin, Li., Guoxin, Sun., Yingjiao Zhang, Jianqiang, Su. and Jun, Ye. (2015). Heavy metal induced antibiotic resistance in bacterium LSJC7. International Journal of. Molecular Science, 16, 23390-23404.

Clinical and Laboratory Standards Institute (CLSI): Performance standards for antimicrobial susceptibility testing (2011) $21^{\text {st }}$ informational supplement M100S21. CLSI, Wayne, Pa.

Das, S.N., Mandal, M., Mandal, S. (2016). Plasmid mediated antibiotic and heavy metal co-resistance in bacterial isolates from Mahananda River Water (Malda, India). Translational Medicine (Sunnyvale) 6, 185.

Das, S.N., Mandal, M., Mandal, S. (2018). Detection of mercury and cadmium resistance among multiple antibiotic resistant enteric bacteria from municipal sewage water in Malda, India. International Research Journal of Pharmacy, 9, (in press).

Dhanorkar, D.V. and Tambekar, D.H. (2004). Studies on multidrug resistance pattern of clinical isolates. 45th Annual Conference of Association of Microbiologist of India, NDRL, (Karnal), November 23-25, 2004 
Doddaiah V., Anjaneya D. (2014). Prevalence of ESBL, AmpC and Carbapenemase among Gram Negative Bacilli isolated from clinical specimens. American Journal of Life Sciences, Vol. 2, No. 2, 76-81.

Fang, L. et al. (2016). Co-spread of metal and antibiotic resistance within ST3-IncHI2 plasmids from E. coli isolates of foodproducing animals. Sci. Rep. 6, 25312; doi: 10.1038/srep25312 (2016).

Filali, B.K., Taoufik, J., Zeroual, Y., Dzairi, F.Z., Talbi, M., Blaghen, M. (2000). Waste water bacterial isolates resistant to heavy metals and antibiotics. Curr. Microbiol., 41, 151156.

Foster, TJ. (1983). Plasmid-determined resistance to antimicrobial drugs and toxic metal ions in bacteria. Microbiol Rev 47, 361-409.

Garhwal D., Vaghela G., Panwala T., Revdiwala S., Shah A., Mulla S. (2014) Lead tolerance capacity of clinical bacterial isolates and change in their antibiotic susceptibility pattern after exposure to a heavy metal. International Journal Med Public Health, 4,253-6.

Kado, C.I., Liu, S.T. (1981). Rapid procedure for detection and isolation of large and small plasmids. Jaurnal of Bacteriology, $145,1365-1373$.

Kaneene, B.J., Miller, R., Sayah, R., Johnson, Y.J., Gilliland, D., Gardiner, J.C. (2007). Considerations when using discrimination function analysis of antimicrobial resistance profiles to identify sources of faecal contamination of surface water in Michigan. Appl Environ Microbial, 73, 2878-90.

Karbasizaed, V., Naser Badami1, Giti Emtiazi. (2003) Antimicrobial, heavy metal resistance and plasmid profile of coliforms isolated from nosocomial infections in a hospital in Isfahan, Iran. African Journal of Biotechnology 2, 379383.

Krumperman, P.H. (1983). Multiple antibiotic resistance indexing of Escherichia coli to identify high-risk sources of fecal contamination of foods. Appl Environ Microbiol 46, 16570.

Malema, M.S., Akebe Luther King Abia, Roman Tandlich, Bonga Zuma, Jean-Marc Mwenge Kahinda and Eunice UbombaJaswa. (2018). Antibiotic-resistant pathogenic Escherichia coli isolated from rooftop rainwater-harvesting $t$ anks in the Eastern Cape, South Africa. Int. J. Environ. Res. Public Health, 15, 892; doi:10.3390/ijerph15050892

Mandal, S. (2015). Can over-the-counter antibiotics coerce people for self-medication with antibiotics? Asian Pac J Trop Dis 5: S184-S186.

Mandal, S., Deb, Mandal, M., Pal, N.K. (2008). Plasmid encoded UV resistance and UV induced ciprofloxacin resistance in Salmonella enterica serovar Typhi. Int J Integrat Biol 2: 4348.

Maniatis T., Fritsch E.F., Sambrook J. (1982). Molecular cloning: A laboratory manual. Cold Spring Harbor Laboratory: New York.
Mustapha, M.U., Halimoon, N. (2015). Screening and isolation of heavy metal tolerant bacteria in industrial Effluent. Procedia Environmental Sciences, 30, 33 - 37.

Nakahara, H., Tomoaki Ishikawa, Yasunaga Sarai, Isamu Kondo, Susumu Mitsuhashi. (1977). Frequency of heavy-metal resistance in bacteria from inpatients in Japan. Nature, 266, 165-167.

Oko, J.O., Umar, M., Akafyi, D.E., Abdullahi, M. (2016). Antibacterial susceptibility of heavy metals tolerant bacteria isolated from NILEST tannery effluent. Journal of Advances in Medical and Pharmaceutical Sciences, 8, 1-10.

Pokhrel, H., Sangipran Baishya1, Bipul Phukan1, Devika Pillai and Mohd Ashraf Rather. (2018).Occurrence and distribution of multiple antibiotic resistance bacteria of public health significance in backwaters and aquaculture farm. Int.J.Curr. Microbiol.App.Sci, 7 (2), 975-987.

Rajasekar, S., Mohankumar A.(2016). Antibiotic susceptibility and plasmid profile of heavy metal resistant Pseudomonas species. Biosci. Biotech. Res, Comm, 9(2), 211-215.

Sandhu, R., Shalley Dahiya, Pallavi Sayal. (2016). Evaluation of multiple antibiotic resistance (MAR) index and Doxycycline susceptibility of Acinetobacter species among inpatients. Indian J Microbiol Res, 3(3):299-304.

Smith, DH. (1967) R Factors mediate resistance to mercury, nickel, and cobalt. Science, 156, 1114-1116.

Subramani S., Vignesh, S. (2012). MAR Index study and MDR character analysis of a few golden Staphylococcus isolates. Asian Journal of Pharmacy and Life Science 2, 151-154.

Sutterlin, S., Téllez-Castillo C.J., Anselem L., Yin H., Bray J.E., Maiden M.C.J. (2018). Heavy metal susceptibility of Escherichia coli isolated from urine samples from Sweden, Germany, and Spain. Antimicrob Agents Chemother, 62, 209-18.

Tambekar, D.H., Hirulkar, N.B., Waghmare, A.S. (2005). MAR indexing to discriminate the source of faecal contamination in drinking water. Nat Environ Poll Tech, 4, 525-8.

Tenover, F.C. (2006). Mechanisms of antimicrobial resistance in bacteria, American Journal Infect Cont, 34, S3-S10.

Wales, A.D. \&t Davies, R. H. (2015). Co-selection of resistance to antibiotics, Biocides and Heavy metals, and Its relevance to food borne pathogens. Antibiotics. 4, 567-604.

Wright, M.S., Gretchen Loeffler Peltier, Ramunas Stepanauskas \& J Vaun McArthur. (2006). Bacterial tolerances to metals andantibiotics inmetal-contaminated and reference streams. FEMS Microbiol Ecol, 58, 293-302.

Yamina, B., Tahar, B., Lila, M., Hocine, H. and Laure, F.M. (2014) Study on cadmium resistant-bacteria isolated from Hospital wastewaters. Advances in Bioscience and Biotechnology, 5, 718-726.

Zhu, Y.G., Johnson, T.A., Su, J., Qiao, M.. Guo, G.X., Stedtfeld, R.D., Hashsham, S.A., Tiedje, J.M. (2013) Diverse and abundant antibiotic resistance genes in Chinese swine farms. Proc. Natl. Acad. Sci. USA, 110, 3435-3440. 